\title{
Quality optimization of branding for perspective Russian automobile brands
}

\author{
Dmitry Radushinsky ${ }^{1, *}$ Anastasiya Fedosina ${ }^{2}$ and Tatyana Pokrovskaya ${ }^{3,4}$ \\ ${ }^{1}$ St. Petersburg Mining University, 21 line, 2, Vasilievsky Island, 199106, St. Petersburg, Russi \\ ${ }^{2}$ Moscow State University of Civil Engineering, 26, Yaroslavskoye Shosse, 109377, Moscow, Russia \\ ${ }^{3}$ Moscow Polytechnic University, Bolshaya Semenovskaya str., 38, 107023, Moscow, Russia \\ ${ }^{4}$ Moscow Financial Industrial University" Synergy, Izmailovsky Val, 2, 105318, Moscow, Russia
}

\begin{abstract}
The article identifies the current approaches and describes some promising attitude of promoting new domestic automobiles (cars), both by means of classical and modern branding. The proposed attitude is based on optimization of marketing and technological goals of production and sales process of a complex long-duration good conducted under premium domestic (Russian) trade mark (brand). As a methodological basis, the article uses a framework of the Volga Siber brand concept positioning, presented by the National Guild of Marketers for the release of a Russian e-class car in 2008. As well the current statistics and sociological assessment has been taken into account in this research. The article describes the entity and the main features of the target group of consumers of e-class car, methods of optimizing the quality of branding for an e-class long-duration good, car, produced under a Russian trademark.
\end{abstract}

\section{Introduction}

The aim of this work is to determine the components of an approach to optimizing the quality of branding, positioning, promotion among Russian and foreign consumers (buyers) of various social strata of cars produced under Russian trademarks. The main research methods are analytical methods of analysis and synthesis.

It should be noted that the car in the modern world, the so-called "consumer society", is for most people (consumers) an important part not only of everyday life, but also of such aspects of its perception and evaluation as: the possibility of self-affirmation, embodiment and (or) association ourselves with aesthetic and technical ideals, progress and the art of design. The car is a reflection of a part of the "inner world" of the consumer, represented by the synthesis of his own accumulated experience of use, various needs, ideals, interests, habits and hobbies. When choosing a car, the owner takes into account various types of messages from people who are significant for the consumer, including those who are personally significant for the buyer - relatives, close people, "opinion leaders" of his social group, "messages" of car advertising and the appearance of the brand of the manufacturer (its long-term and the newly created image). The messages relate to the functional

\footnotetext{
* Corresponding author: D.Radoushinsky@gmail.com
} 
characteristics of technical performance, technological innovations, intangible characteristics - social and all other aspects that make up the "brand capital" representing a particular car model. Also, when deciding to purchase a car, the current policy of car dealerships to stimulate sales (incentives), corporate communication are taken into account, an important factor is the personal charm of the representatives of the car dealership personnel $[1,2]$.

\section{Applied methodology, research materials}

A qualitative study was carried out, the main presupposition for which the author consider the opportunity to analyze and identify the applied approaches and promising directions for promoting new domestic automobiles, both by means of classical and modern branding and marketing.

\subsection{The actual features of automobile branding}

When analyzing the age characteristics of a consumer choosing a car and its brand, expert most often distinguish three segments of the target audience. For many young people (1825 / 30 years old, young) entering their "adult" life, the car is an important symbolic (sometimes "cult") object, reflecting not only the level of material well-being of the family, but also individual (personal) ambitions, aspirations, ideas about aesthetics and ideals. It symbolizes growing up and sometimes reflects his own first successes and achievements. In the future, for the main group of consumers - "mature" (25 / 30-55 / 60 years old, mature), which is formed as young people are involved in professional activities and family life, their choice of a car is dictated by a combination (to one degree or another ) family and career values, a declaration of social status. In this case, important factors are not only the functionality of the car in meeting personal and / or family needs and hobbies, but also the image (the degree of "handshake-ness") of the car brand for the social group that is significant for the consumer, with which he associates himself at one stage or another of his life path, e. g. colleagues, friends, neighbors or the "homogeneous social environment" of a person...

With regard to the remaining third large part of the age audience, we note that during the period of retirement and preparation for it, the choice of a car and its brand by elderly citizens (55 / 60-75 years old, or senior citizens, as this age group is consistently called in economic literature), which belong to the middle class, has certain characteristics. Researchers note that most often in this age group, the choice is made in favor of a car in terms of cost and size, somewhat more modest (by 20-30\%) than the "conventional" image that they could afford during the years of fruitful work and career growth. At the same time, the key requirements are the maximum functionalism of the car, its reliability and long service life, taking into account the limitations of the existing level of income of an elderly couple and (or) their children, capable of satisfying the basic needs of an "extended" family, in which it is important for a mature and elderly couple to have the opportunity perform various functions of "grandparents".

Note that still relatively recently, in the 1990s - 2000s, most people who retired in Russia could not afford to buy a car, including a new one. During this period, the retirement period was synonymous with a period of no significant income. With the advent of solid military pensions, pensions for civil servants in the 2010s and the formation of a class of elderly "rentiers" who made a fortune earlier, the category of car owners «senior citizens» (over 55/60 years old) is gaining increasing importance [3,4,5]. When designing a new Russian e-class car and creating programs to promote its brand, it is necessary to take into 
account the prospects that this particular age category has the opportunity to become a "pioneer" target audience for such a brand.

The marketing features of the implementation of work on positioning, creating a longterm image, promotion, branding, ongoing advertising and car sales stimulation differ significantly depending on the age of the target group. The increased attention of researchers, including in Russia [6,7,8], attracts the largest group of target audience of car buyers - "mature consumers", from $25 / 30$ to 55/60 years. Thus, in work [7], the types of passenger car consumers are identified depending on their lifestyle and the corresponding communication strategies are analyzed, designed to best influence: individual consumers, families and households, intermediaries, suppliers, officials. The most effective tools of influence ("variables") for conditional psychological categories (strata) of consumers: "calculating", "enthusiasts", "lovers of comfort", "those who have succeeded in life" have been identified.

Within the framework of this study, it seems relevant to clarify the marketing concept of the most significant target group "calculating" in order to focus and fine-tune potential consumers of the Russian e-class car brand within this stratum. To do this, it is important to distinguish the motives driving the representatives of the group into two components. One of these components is the "accounting" prudence of a group of consumers caused by necessity - in accordance with the classic contradiction of the philosophical concepts of "freedom" versus "necessity". It is "necessary" to fit into the "tight budgetary constraints" by purchasing a durable item - a car (like, for example, an apartment) that optimally satisfies the current spectrum of vital needs.

Another part of the motive of "prudence" has a different nature from the motive of "necessity" and is associated with the manifestation of "freedom" (independence) of the consumer through his self-affirmation in the social environment. In the advertising messages of many products - from FMCG advertising to real estate - in recent years, the English-language term "smart" has spread, which reflects the "intelligence" of the consumer not only in relation to his own circumstances (associated with "needs"), but also means some of it. superiority over other consumers with separation ("detuning") from those groups of people and consumers who are less "smart" ("prosharen" in Russian current slang). Representatives of the group of especially "smart" consumers often copy the "habits" and consumption styles of the "successful in life" group, while the "successful in life" group in terms of consumption style often coincides with the "innovators" group (according to the more widely known marketing division ). For a subgroup of "smart (smart) - prudent" that is significant in terms of the number of car buyers, it is especially important to demonstrate various attributes of one's own exclusivity, often superiority over those who are less "successful". Such copying refers to the described style of behavior of the group of "imitators" (repeaters) as part of the traditional marketing division of consumers into groups of "innovators", "imitators", "early" and "late" majority and "conservatives". The most often imitators are not rich enough, but ambitious young people, whose lifestyle and consumption style is described both in scientific economic (for example, T. Veblen "Idle class") [9], and in fiction (for example, T. Dreiser, trilogy "The Financier") [10] and cinema (for example "The Wolf of Wall Street" by Martin Scorsese and the story by Jordan Belfort [11] and other fiction series works).

For the purposes of this work, we note that a feature of the sign system of the marketing category of the "success" group is the possession and demonstration of certain consumer goods within the framework of social communication. In the Soviet republics in the 19701980 s and in the CIS countries in the 1990s, this set was somewhat different from the corresponding iconic set of objects that had developed by that time in the countries with the most developed economies. In the Soviet period, such items could serve, in particular, imported jeans, sneakers, then VCRs and other inaccessible "artifacts" produced abroad (in 
Russian it sounds as a "made in ..." with a German accent). In modern reality, in the 20102020 s, in addition to clothing items for consumers in Russia, the car plays a role and in the near future will continue to play the role of a key attribute signaling belonging to "one's" social group - close in life attitudes, values and level material well-being of consumer groups. The size of the target audience of car consumers in Russia by the mentioned social classes can be estimated as follows (Table 1).

Table 1. Assessment of the composition, main features and number of the target audience of car buyers in Russia by categories (strata) and depending on the ability to pay, 2020.

\begin{tabular}{|c|c|c|c|c|}
\hline $\begin{array}{l}\text { Age. } \\
\text { years }\end{array}$ & $\begin{array}{l}\text { Social } \\
\text { group } \\
\text { (stratum. } \\
\text { category) }\end{array}$ & $\begin{array}{l}\text { Comments (main socio- } \\
\text { psychological. professional traits } \\
\text { and associations of the stratum. } \\
\text { its values) }\end{array}$ & $\begin{array}{l}\text { Total } \\
\text { potential } \\
\text { number. } \\
\text { thousand } \\
\text { people } / \% \text { of } \\
\text { the total }\end{array}$ & $\begin{array}{l}\text { Including the } \\
\text { annual solvent* } \\
\text { audience. } \\
\text { thousand } \\
\text { people / \% of } \\
\text { the total }\end{array}$ \\
\hline 1 & 2 & 3 & 4 & 5 \\
\hline \multirow{4}{*}{$\begin{array}{l}18- \\
25\end{array}$} & Smart & $\begin{array}{l}\text { Ambition. passion. ideals. opening } \\
\text { opportunities. extreme sports } \\
\text { enthusiasts }\end{array}$ & $5000 / 6.0 \%$ & $70 / 4.1 \%$ \\
\hline & $\begin{array}{l}\text { Lovers of } \\
\text { comfort }\end{array}$ & $\begin{array}{l}\text { Confidence in the future. Interest in } \\
\text { auto innovation. Interest in } \\
\text { features. attention to detail. e.g. } \\
\text { regarding to auto }\end{array}$ & $500 / 0.6 \%$ & $25 / 1.5 \%$ \\
\hline & Successful & $\begin{array}{l}\text { "New" or "old" rich (nouveau rich } \\
\text { or aristocracy) belonging to } \\
\text { families or clans with extra } \\
\text { resources }\end{array}$ & $200 / 0.2 \%$ & $12 / 0.7 \%$ \\
\hline & Conservatives & $\begin{array}{l}\text { A car inherited from an older } \\
\text { generation or a new economy-class } \\
\text { brand chosen by (or with) parents }\end{array}$ & $5000 / 6.0 \%$ & $150 / 8.9 \%$ \\
\hline \multirow{4}{*}{$\begin{array}{l}25- \\
55\end{array}$} & Smart & $\begin{array}{l}\text { Emphasize their special status } \\
\text { (mid-level manager. high-class } \\
\text { specialist). Do not miss significant } \\
\text { technical innovations. to be in the } \\
\text { "trend" }\end{array}$ & $12000 / 14.4 \%$ & $350 / 20.7 \%$ \\
\hline & $\begin{array}{l}\text { Lovers of } \\
\text { comfort }\end{array}$ & $\begin{array}{l}\text { Spouses in wealthy couples. people } \\
\text { temporarily living independently } \\
\text { and "convinced" bachelors who } \\
\text { value independence }\end{array}$ & $4000 / 4.8 \%$ & $125 / 7.4 \%$ \\
\hline & Successful & $\begin{array}{l}\text { Status cars for high-ranking } \\
\text { executives. owners of capital assets } \\
\text { ("bosses") }\end{array}$ & $2000 / 2.4 \%$ & $80 / 4.7 \%$ \\
\hline & Conservatives & $\begin{array}{l}\text { Cars are "workhorses": economical. } \\
\text { functional. purchased at a discount. } \\
\text { with additional options. etc. Often } \\
\text { parents help their children to buy }\end{array}$ & $35000 / 42.1 \%$ & $500 / 29.6 \%$ \\
\hline \multirow{3}{*}{$\begin{array}{l}55- \\
75 \\
\text { and } \\
\text { more }\end{array}$} & Smart & $\begin{array}{l}\text { Technically modern and passable } \\
\text { vehicle. allowing. for example. to } \\
\text { get fishing and hunting in remote } \\
\text { and difficult-to-pass places }\end{array}$ & $6500 / 7.8 \%$ & $100 / 5.9 \%$ \\
\hline & $\begin{array}{l}\text { Lovers of } \\
\text { comfort }\end{array}$ & $\begin{array}{l}\text { Stylish looking car with a touch of } \\
\text { "youth" and "recklessness". to stay } \\
\text { young (the idea is reflected in the } \\
\text { movie "The Smell of a Woman") }\end{array}$ & $500 / 0.6 \%$ & $25 / 1.5 \%$ \\
\hline & Successful & $\begin{array}{l}\text { An expensive car. often not the } \\
\text { only one in the garage (car fleet) of }\end{array}$ & $500 / 0.6 \%$ & $50 / 3.0 \%$ \\
\hline
\end{tabular}




\begin{tabular}{|l|l|l|l|l|}
\hline & a "personal pensioner" & & \\
\cline { 2 - 4 } & $\begin{array}{l}\text { A functional and durable car for the } \\
\text { "extended family" (for } \\
\text { "grandfather / "grandmother"). } \\
\text { Often. children help their parents } \\
\text { acquire. }\end{array}$ & $12000 / 14.4 \%$ & $200 / 1.9 \%$ \\
\hline \multicolumn{2}{|l|}{} & $83200 / 100 \%$ & $1687 / 100 \%$ \\
\hline
\end{tabular}

Notes: Table 1 was compiled by the author. All categories of target audience of buyers also include sales of cars for taxis.

*payable.

It is noteworthy that the level of "conversion" - the transformation from a potential buyer into a real one in a particular year for various target groups differs significantly (see columns of Table 1 "total potential number" and "including the annual paying audience" №№4,5). The highest conversion is in the strata "successful" and "comfort lovers", where there are many individual consumers, and the lowest conversion rate is in the stratum "conservatives", where most of the families with one car and buyers who would like to, but could not afford to buy a car. Conditional social values of superiority (smart - audience), domination and exclusivity ("successful") are especially high for age groups of buyers up to $55 / 60$ years, however, for senior citizens, the durability and functionality of the car is becoming increasingly important.

It is known that the level of sales of passenger cars in Russia in 2005-2019 fluctuated between 1.3-2.8 million cars per year, reaching peaks in 2008 and 2012 and minimums in 2009 and 2016. In 2018-2020, according to statistics and forecast, the level of sales is about 1.75 million vehicles per year. In comparison with the sales peaks reached, it can be concluded that in the next decade 2020-2030, with an increase in household income, annual sales may increase to 2.5-3 million cars per year.

\subsection{Reflection of the national spirit of the manufacturer, and its combination with the mental and psychological values of consumers when choosing a car brand}

The identification of national characteristics in the production and branding of cars is the topic of a significant and separate national marketing, cultural and art research, however, in this article it was decided to outline the main contours for the spectrum of existing ideas and prospective studies on this topic.

According to the founder of one of the leading auto-tuning ateliers in the United States, "in the modern world, a car is primarily the image of its owner, a reflection of his inner world," created with the aim of "standing out, staying bright, inspiring respect, emphasizing his individuality, realizing his ambitions. "Unleash your beast" -. This message is implemented by each layer (stratum) of auto-consumers in its own way, despite the fact that the number of consumers who are objectively freed from the implementation of current needs and are not tied to the need to observe the principle of economical functionality when choosing a car is relatively small. The realization of one of the highest groups of needs according to the Maslow pyramid, associated with self-affirmation and demonstration of status, through the fulfillment of the need to "remain bright and inspire respect", can potentially be made for a specific consumer at each of the conventional levels (economy, average , premium) produced cars. At the same time, from the point of view of the "successful" ("connoisseurs of life"), it may seem that objective self-assertion is realized only in the elite auto segment by consumers who feel and materialize their exclusivity in everything. 
However, in our opinion, I use certain attributes, which may include "mythological", including national, features of the car and its brand, it is possible to achieve quite high results in idealizing the features of the car in the eyes of the owner and his reference group. The technique of creating an ideal product image for your group of consumers is used in branding almost all cars. Some manufacturers successfully form and (or) use a previously formed image about the quality and characteristics of their cars, including on the basis of references and associations to national characteristics, prevailing and generally accepted "myths". Accordingly, segments of auto preferences have formed on the Russian automotive market, not only by price and class, but also by country - by manufacturer. The dominant "myths" of national automakers have been formed: Germany - superiority and belonging to the "successful" with the possession of Porshe, Mercedes, BMW, Audi, quality and durability of VW and Opel; Sweden - focus on Volvo safety; South Korea - best value for money Kia, Huyndai and Ssang-Yong, and so on. "Myths" and "their own" groups of connoisseurs - consumers have cars from the USA, Japan, Great Britain and other European countries, and in recent decades - from China.

The identification of national characteristics in the production and branding of cars is the topic of a significant and separate national marketing, cultural and art research research, however, in this article it was decided to outline the main contours for the spectrum of existing ideas and prospective studies on this topic.

According to the founder of one of the leading auto-tuning ateliers in the United States, "in the modern world, a car is primarily the image of its owner, a reflection of his inner world," created with the aim of "standing out, staying bright, inspiring respect, emphasizing his individuality, realizing his ambitions, "Unleash your beast" ... ". This message is implemented by each layer (stratum) of auto-consumers in its own way, despite the fact that the number of consumers who are objectively freed from the implementation of current needs and are not tied to the need to observe the principle of economical functionality when choosing a car is relatively small. The realization of one of the highest groups of needs according to the Maslow pyramid, associated with self-affirmation and demonstration of status, through the fulfillment of the need to "remain bright and inspire respect", can potentially be made for a specific consumer at each of the conventional levels (economy, average , premium) produced cars. At the same time, from the point of view of the "successful" ("connoisseurs of life"), it may seem that objective self-assertion is realized only in the elite auto segment by consumers who feel and materialize their exclusivity in everything.

The attitude formed in the 1980s-2010s among a significant number of consumers "opinion leaders" in large cities of the central western part of the country towards domestic car manufacturers is a skeptical, wary-suspicious attitude, often arrogant and sarcastic jokes that "disparage" Russian cars with The "heights" of the opinions of those who "cognized" the "real" quality (German, Japanese, and so on). Based on the analyzed survey data, it can be argued that the described attitude of the masses of consumers to Russian auto brands (Lada, Volga, UAZ) is due not only to a radical decline in the quality of car production in the 1990s, but is also a reflection of deeper features characteristic of the Russian mentality. So, one cannot fail to note the phenomenon of "servility" before the foreign ("Western"), vividly described in the fiction of the XIX-XXI centuries, starting from the works of P.A. Chaadaev and de Kustrin to the works of A.P. Chekhov, F.M. Dostoevsky, Danilevsky and other famous authors of the 19th century $[12,13,14,15,16]$. Also, in the works of some contemporary authors in an actual artistic form, some existing mental and psychological characteristics and values of consumers of the Russian "middle class", its various strata, as an object of advertising, information and propaganda influence are described (for example, V.O. Pelevin: "Generation Pi "(1993),"The Numbers "(2002),"iPhuck 10"(2017) [17]; some works by S. Minaev [18] and other authors). 
The issue of skepticism towards the products of a Russian manufacturer - not in all cases objective - has not been sufficiently studied in modern literature on economics, marketing, PR (public relations), as well as branding, consumer psychology and sociology. We believe that the overcoming of this limitation is decisive for the success of the processes of strategic branding by the manufacturing company and car dealers of durable civil goods $[19,20]$, which is a domestically produced car.

It is now possible to outline some of the contours of the "battlefield" and the competing sides in "battles for the consumer." It is possible to describe some images associated with previously produced and modern brands of automakers (with certain national features), as well as some image of a "paladin", "hero", "brand advocate", in "commonwealth" with which a promising Russian e-class car could to jointly create and "charge" the target audience. It is advisable to determine in advance those foreign brands of cars (brands and manufacturing plants) with which such a car, most likely, will have to interact not within the framework of cooperation, but within the framework of competition. Competition will include, among other things, the values supported and actualized by each of the brands and each of the groups of their carriers, possibly in conjunction with broader groups of cultural, aesthetic, moral, ethical and other value orientations of modern marketing [21, 22, 23].

\section{Results}

\subsection{Implementation of $\mathbf{N}$. Kano's approaches in optimizing the composition of operational and "intangible" qualities and characteristics of an automobile}

As the realization of the issue aim the author implemented some of N. Kano's approaches in optimizing the composition of operational and "intangible" qualities and characteristics of a car, maximizing the "value" of the consumer in the successful development of well-known car manufacturers and the creation of car brands. Developed and widely used in Japan and other countries, the marketing and management theorist Noriaki Kano's approach to the aspects of product value allows the creation of new products and their modifications, both in the consumer and industrial markets, to rely on a phased model that has a successful working structure [24]. The advantage of the Kano concept is that, within the framework of the systems used to maintain and improve the quality of production, known abroad, when designing a new car and promoting it, both the most desirable properties of the product and those that can be taken into account in accordance with in-depth research of the target audience potentially alienate the consumer.

Conventionally, the characteristics of some brands and models of modern cars in accordance with N. Kano's approach can be represented as follows (Table 2).

Table 2. The main characteristics of a number of the best-selling passenger cars on the Russian market (by the number of units sold in 2018-2020) in accordance with N. Kano's approach.

\begin{tabular}{|c|c|c|c|c|}
\hline $\begin{array}{c}\text { Car } \\
\text { brand, } \\
\text { model }\end{array}$ & $\begin{array}{l}\text { Price } \\
\text { range, } \\
\text { thousand } \\
\text { rubles / } \\
\text { thousand } \\
\text { USD }\end{array}$ & $\begin{array}{c}\text { Capable of causing } \\
\text { «admiration» of the } \\
\text { consumer car } \\
\text { characteristics and } \\
\text { features of its brand / } \\
\text { image }\end{array}$ & $\begin{array}{c}\text { Basis of a } \\
\text { functional set of } \\
\text { properties }\end{array}$ & $\begin{array}{l}\text { Capable of } \\
\text { repelling the } \\
\text { consumer } \\
\text { properties }\end{array}$ \\
\hline 1 & 2 & $\mathbf{3}$ & 4 & 5 \\
\hline $\begin{array}{l}\text { UAZ } \\
\text { Patriot }\end{array}$ & $850 / 12$ & $\begin{array}{ll}\text { powerful, } & \text { Russian } \\
\text { brand }\end{array}$ & $\begin{array}{l}\text { cross-country } \\
\text { passable }\end{array}$ & flowing rear axle \\
\hline $\begin{array}{ll}\text { Lada } & \mathrm{X}- \\
\text { Ray } & \\
\end{array}$ & $\begin{array}{l}800-1100 \\
11-15\end{array}$ & original body design & AWD mode & $\begin{array}{l}\text { expensive in } \\
\text { comparison }\end{array}$ \\
\hline
\end{tabular}




\begin{tabular}{|c|c|c|c|c|}
\hline Lada Vesta & $\begin{array}{l}450-700 / 7- \\
10\end{array}$ & - & $\begin{array}{l}\text { participation of the } \\
\text { Nissan-Renault }\end{array}$ & $\begin{array}{l}\text { technical } \\
\text { shortcomings }\end{array}$ \\
\hline $\begin{array}{l}\text { Kia } \\
\text { Sportage }\end{array}$ & $1900 / 26$ & $\begin{array}{l}\text { design, image of the } \\
\text { car of an active person }\end{array}$ & \multirow{2}{*}{$\begin{array}{l}\text { high-quality Korean } \\
\text { brand }\end{array}$} & \multirow{2}{*}{$\begin{array}{l}\text { some technical } \\
\text { shortcomings }\end{array}$} \\
\hline $\begin{array}{l}\text { Kia } \\
\text { Optima }\end{array}$ & $1700 / 23$ & stylish design & & \\
\hline $\begin{array}{l}\text { Nissan } \\
\text { Quashqai }\end{array}$ & $\begin{array}{l}1400-2000 \\
/ 20-30\end{array}$ & \multirow{2}{*}{$\begin{array}{l}\text { good price / quality } \\
\text { ratio; Japanese design }\end{array}$} & \multirow{2}{*}{$\begin{array}{l}\text { available at dealing } \\
\text {-centers, produced / } \\
\text { not produced on the } \\
\text { territory of Russia, }\end{array}$} & \multirow{2}{*}{$\begin{array}{l}\text { some technical } \\
\text { flaws, the } \\
\text { capabilities of the } \\
\text { SUV }\end{array}$} \\
\hline $\begin{array}{l}\text { Mitsudushi } \\
\text { Outlander }\end{array}$ & $\begin{array}{l}1400-2000 \\
/ 20-30\end{array}$ & & & \\
\hline $\begin{array}{l}\text { Scoda } \\
\text { Octavia }\end{array}$ & $1700 / 23$ & $\begin{array}{l}\text { image ("brand equity") } \\
\text { of Czech-German cars }\end{array}$ & $\begin{array}{l}\text { reliability } \\
\text { maintainability }\end{array}$ & small body size \\
\hline $\begin{array}{l}\text { Renault } \\
\text { Arcana }\end{array}$ & $\begin{array}{l}1400-2000 \\
/ 20-30\end{array}$ & \multirow{4}{*}{$\begin{array}{l}\text { good price / quality } \\
\text { ratio }\end{array}$} & \multirow{4}{*}{$\begin{array}{l}\text { fairly high quality, } \\
\text { reliability } \\
\text { availability } \\
\text { showrooms, in } \\
\text { localization } \\
\text { production, of } \\
\text { cost of repair }\end{array}$} & \multirow{4}{*}{$\begin{array}{l}\text { some technical } \\
\text { shortcomings }\end{array}$} \\
\hline $\begin{array}{l}\text { Renault } \\
\text { Duster } \\
\end{array}$ & $\begin{array}{l}900-1500 / \\
12-17\end{array}$ & & & \\
\hline $\begin{array}{l}\text { Huinday } \\
\text { Creta }\end{array}$ & $\begin{array}{l}1400-2000 \\
/ 20-30\end{array}$ & & & \\
\hline $\begin{array}{l}\text { Huyndai } \\
\text { Solaris }\end{array}$ & $\begin{array}{l}650-1000 / \\
9-15\end{array}$ & & & \\
\hline $\begin{array}{l}\text { Chevrolet } \\
\text { Niva }\end{array}$ & $\begin{array}{l}800-1100 / \\
11-15 / \text { used }\end{array}$ & $\begin{array}{l}\text { first Russian-foreign } \\
\text { car }\end{array}$ & $\begin{array}{l}\text { comparative cross- } \\
\text { country ability }\end{array}$ & $\begin{array}{l}\text { technical } \\
\text { deficiencies, } \\
\text { image }\end{array}$ \\
\hline Rover & Used prices & English car & - & not produced \\
\hline $\begin{array}{l}\text { Mercedes } \\
\text { e200, e220 }\end{array}$ & $\begin{array}{l}2000-2500 \\
/ 30-37\end{array}$ & $\begin{array}{l}\text { image (brand equity) of } \\
\text { the best world } \\
\text { automobile plant / } \\
\text { German manufacturer }\end{array}$ & $\begin{array}{l}\text { reliability, } \\
\text { maintainability }\end{array}$ & \multirow{3}{*}{$\begin{array}{l}\text { comparative high } \\
\text { cost }\end{array}$} \\
\hline $\begin{array}{l}\text { BMW 525, } \\
\text { X3 }\end{array}$ & $\begin{array}{l}2000-3000 \\
/ 30-43\end{array}$ & $\begin{array}{l}\text { "international" and } \\
\text { Russian brand equity } \\
\text { ("boomer") }\end{array}$ & $\begin{array}{l}\text { fast acceleration, } \\
\text { style, quality }\end{array}$ & \\
\hline $\begin{array}{l}\text { Subaru } \\
\text { Forrester }\end{array}$ & $\begin{array}{l}2000-3000 \\
/ 30-43\end{array}$ & $\begin{array}{l}\text { Japanese assembly, } \\
\text { boxer engine, }\end{array}$ & $\begin{array}{l}\text { cross-country } \\
\text { ability, technical } \\
\text { innovations }\end{array}$ & \\
\hline \multicolumn{2}{|c|}{$\begin{array}{l}\text { Cortege, Acura, Audi, } \\
\text { Infinity, Jaguar, Genesys, } \\
\text { Lexus and other premium } \\
\text { auto brands }\end{array}$} & $\begin{array}{l}\text { image (status) } \\
\text { significant series and } \\
\text { brands, less often - } \\
\text { technical and consumer } \\
\text { properties }\end{array}$ & $\begin{array}{l}\text { high quality design, } \\
\text { assemblies, the best } \\
\text { service personnel, }\end{array}$ & $\begin{array}{l}\text { individual } \\
\text { technical } \\
\text { disadvantages, } \\
\text { financial and } \\
\text { psychological } \\
\text { inaccessibility }\end{array}$ \\
\hline
\end{tabular}

Note: Table 2 was compiled by the authors.

Table 2 shows some of the most key features of cars that correspond to N. Kano's approach, related to the sphere of customer experience (the key "place of work" of the brand), as well as to objective technological (sometimes innovative) characteristics and solutions. Since this article discusses the project of launching a mass brand (similar to the Volga class in the USSR), its "lower boundaries" are the most massive economy class cars, and the upper ones are functional or passable (Subaru Forrester and analogues) or fashion cars (BMW, Mercedes) of the most prestigious car brands belonging to the lower price category, produced by this brand. Thus, the extended price range for the e-class car project under study is 800-2400 thousand rubles. Let's preliminary estimate that the most acceptable price for the project under development for a Russian car of this class may be 1.2-1.6 million rubles.

For Nissan Quashqai and Mitsudushi Outlander cars, Table 2 indicates that their properties are "produced or not produced in Russia", "SUV capabilities" are functional. At 
the same time, N. Kano revealed that there is a certain set of product properties, which, depending on the context, can have both positive and negative effects on the buyer ("variable" properties). Bearing in mind, on the one hand, that a significant number of Russian buyers have a persistent prejudice against domestically produced durable goods, and on the other hand, that there is a phenomenon of the so-called patriotic consensus in Russian society, it is possible to conclude that the property is "produced on the territory Russia "will be precisely" variable "according to Kano - for one part of the potential target audience it will serve as an additional factor in the attractiveness of the product, and for another part of it - as a" red rag", a reason for a" negative choice".

Similarly, the fact that the car is a "SUV" (and not a full-fledged "rigid-frame jeep") for some is an attractive property (compared to cars with less cross-country ability), and for others it is a limitation that does not allow making a choice in favor of this car in comparison with a similar vehicle with maximum cross-country ability and frame reliability

\subsection{The basic concept of positioning "Volga Siber" (2008-2010 years of release) and its possible clarifications}

The socio-psychological portrait of a potential consumer of a new Russian car, corresponding to the appearance of the owner of the "premium" car "Volga" for the late Soviet period (1970-1980s), in many key features is formed in the concept of O. Glazunov and A. Strutsinsky on positioning project "Volga Siber", 2008 [25]. An important achievement of the authors, in particular, should be considered the description of the conceptual model of the interaction of signs and symbols reflecting subconscious images, ideals and ideas, with the preferences of consumers and the process of their consumer choice, taking into account the current social, psychological and economic characteristics of Russian reality. The analysis carried out by the authors in 2008 and the conclusions based on it, in our opinion, should be considered applicable for further use in the design and development of a domestic car for consumers of the "upper middle class" ("e-class" car).

The authors proposed such symbolic phrases (mottos, slogans) - elements of "tuning" and positioning for the GAZ "Siber" - as: "the revival of the legend of a large country"; "The car of managers of the corporation" Russia"; "The machine of heroes, people of business and power." Note that today this positioning line has partially found its actual semantic reflection in the emerging image of the domestic brand "Cortege" ("Aurus"), produced for "top officials" of the state since 2019. Due to the high requirements and existing restrictions of the Russian manufacturer, the series of production of these cars, according to the project, will be able to make only hundreds and, possibly, with successful sales in the domestic and foreign markets, the "first" thousand units. The image of a car with such a volume of production corresponds to the image of the ZIS, Chaika and other official vehicles for the upper echelons of management that were previously produced in Russia, as well as the image of foreign brands such as Rolls-Royce or Aston-Martin.

To implement this line of car positioning in a wider consumer segment of responsible persons - managers (managers) who associate themselves with the Russian state and domestic business or with a sustainable business in Russia, certain clarifications and additions are required.

\section{Conclusion}

We consider it necessary to further research the target audience of a promising Russian car of "e-class" - to clarify its size, socio-psychological characteristics and expectations, solvency - to ensure the possibility of building in the future the corresponding characteristics of the car offered to this market. In the concept of "Volga-Siber", it was 
rightly noted that most buyers of passenger brands - "ordinary family men 30-45 years old, a type of European man in the street" can become adherents of the new brand only as "followers", in case of significant success - as "later most". Under the current circumstances, the main category of auto-consumers on the territory of Russia will not independently choose a new domestic car due to a number of stereotypes that have developed and firmly rooted in the 1980s-2000s.

These stereotypes are recreated and disseminated by the Russian public consciousness and partly by the subconscious, by a significant number of "opinion leaders" - "experts in life", often expressing a "well-known" and sarcastic opinion about domestically produced goods, which has spread since the 1960s among those focused on quality subjects consumption of citizens ("materialism"). Often such an opinion is expressed for the purpose of personal self-affirmation of people who have their own "mature" authoritative opinion, make independent critical decisions and do not allow themselves to be "easily" deceived by the "scoop system" and the domestic manufacturer, as well as a reason for associating themselves with romanticized image of superior quality, manufacturability, "creativity" and original design that take place in those countries and their manufacturing plants "where we are not", and about which, such "low-worshiping" citizens, as they were previously called, are often known only through tourist trips and by hearsay (a similar situation was described at the end of the 19th century by A.P. Chekhov).

\section{References}

1. D. Court, D. Elzinga, S. Mulder, O.J. Vetvik, McKinsey Quaterly 3, 3-16 (2009)

2. F. Kotler, H. Cartajaya, A. Setiavan, Marketing 3.0. From products to consumers and further to the human soul (Moscow, Eksmo, 2011)

3. P. Fox, P. Gorman, J. Hatch, Energy 122, 203-213 (2018)

4. J. Kester, B.K. Sovacool, V. Heida, Energy Research \& Social Science 56, 101204 (2019) doi.org/10.1016/j.erss.2019.05.014

5. A. Freeman, Scientific Works of the Free Economic Society of Russia 3(223), 583-594 (2020) DOI: 10.38197/2072-2060-2020-223-3-583-594

6. A.P. Savich, Molodiy Vcheniy 10-2(25), 73-76 (2015)

7. S.A. Lochan, D.V. Fedyunin, Innovations and investments 11, 113-117 (2015)

8. N.E. Akopov, Bulletin of the Tomsk State University 316, 127-129 (2008)

9. T. Veblen, The Theory of the Leisure Class (Macmillan, 1899)

10. T. Dreiser, The Financier; The Titan; The Stoic (Harper \& Brothers, 1912, 1914, 1947)

11. M. Scorsese J.R., Belfort, The Wolf of Wall Street (Paramount Pictures, 2013)

12. P.Ya. Chaadaev, Lettres philosophiques (Paris, 1836)

13. Astolphe de Custine, La Russie en 1839 (Paris, 1843)

14. F.M. Dostoevsky, Complete works in 30 volumes (Leningrad: Science, 1982)

15. N.Ya. Danilevsky, Russia and Europe (Moscow, Vehi, 1869)

16. A.P. Chechov, Complete works in 18 volumes (Leningrad, 1988)

17. V. Pelevin, iPhuck 10 (Eksmo, 2017)

18. S. Minaev, Duchless of XXI century. Selfie (Moscow, Astrel, 2015) 
19. E.A. Kremcheev, D.S. Gromyka, D.O. Nagornov, Journal of Physics: Conference Series. International conference complex equipment of quality control laboratories, 012021 (Saint-Petersburg, 2018).

20. D. Radushinsky, A. Mottaeva, IOP Conference Series: Earth and Environmental Science 90(1), 012137 (2017) DOI: https://doi.org/10.1088/1755-1315/90/1/012137

21. A. Bulanov, Tomorrow marketing (Saint-Petersburg, Publishing House "Peter", 2008)

22. D.A. Radushinskiy, Ye.A. Krylova, Problems of modern economics 2, $42-46$ (2010)

23. E.A. Kremcheev, D.A. Kremcheeva, Opcion 35(19), 3052-3066 (2019)

24. N. Kano, Continuous Improvement: Quality Control Circles in Japanese Industry. Guide to TQM in Service Industries (Asian Productivity Org., 1989, 1996)

25. O. Glazunov, A. Strutsinsky, Concept of positioning and promotion of the GAZ "Siber" car, http://rospodderzhka.ru/information 